\title{
Turkey's Interest in Closer Relations with Russia: Global, Regional and Domestic Dynamics
}

\author{
Emre Erşen ${ }^{1}$ ㅇ, Seçkin Köstem² ${ }^{2}$
}

\begin{abstract}
Recently, debates on a shift of axis in Turkish foreign policy have resurfaced. Many analysts perceive the geopolitical alignment between Turkey and Russia as a deliberate Turkish response to its deteriorating ties with the West. The goal of this paper is to shed light on the factors that have fostered the interest of the Turkish political elite in developing strategic relations with Russia. We argue that Turkey's alignment with Russia has global, regional and domestic dimensions. First, especially after the global financial crisis of 2008, Russia managed to successfully realign itself with rising powers like China and India, while also strengthening its traditional position as a global player. Second, in addition to its strong influence in the Black Sea, the Caucasus and Central Asia, Russia has become a major actor in other regions in the immediate neighborhood of Turkey such as the Middle East and the East Mediterranean. Finally, the failed coup attempt of July 2016 in Turkey has added a strong psychological dimension to the Turkish-Russian rapprochement. Nevertheless, Turkey's interest in closer ties with Russia is not expected to lead to a reorientation in Turkish foreign policy away from its position in the traditional transatlantic alliance.
\end{abstract}

\section{Keywords}

Turkey, Russia, Foreign Policy, Alignment, Syria

1 Corresponding author: Emre Erşen (Assoc. Prof. Dr.), Marmara University, Faculty of Political Science, Political Science and International Relations Department, Istanbul, Turkey. E-mail: eersen@marmara.edu.tr Orcid: 0000-0001-6984-9908

2 Seçkin Köstem (Asst. Prof. Dr.), Bilkent University, Economics, Administrative and Social Sciences Faculty, Department of International Relations, Ankara, Turkey. E-mail: kostem@bilkent.edu.tr Orcid: 0000-0001-8356-444X

To cite this article: Ersen, E., \& Kostem, S. (2020). Turkey's Interest in Closer Relations with Russia: Global, Regional and Domestic Dynamics. SiYASAL: Journal of Political Sciences, 29(2), 231-245. http://doi.org/10.26650/ siyasal.2020.29.2.0026 


\section{Introduction}

In June 2019, the first shipment of the Russian S-400 long-range air defense missile system arrived in the Mürted Air Base in Ankara in accordance with the agreement signed two years earlier between President Erdoğan and President Putin. This remarkable development made Turkey the second country in the world after China and the first and only NATO member state to have purchased these advanced Russian strategic weapons. Against the background of the deepening rift between Russia and the West following the crisis in Ukraine, repeated US warnings that the delivery of the Russian S-400 missiles could trigger a series of sanctions against Turkey and evolving geopolitical alignment between Ankara and Moscow with regard to the Syrian civil war, many analysts claimed that the S-400 issue should be viewed as a sign of the shift of axis taking place in Turkish foreign policy. Accordingly, the strategic rapprochement between Turkey and Russia in the last few years has been perceived as a deliberate Turkish response to its deteriorating ties with the West (Johnson \& Gramer, 2019; Karlıdağ \& Borshchevskii, 2019).

Although it can be claimed that the improvement of political, economic and military relations between Ankara and Moscow has become much more visible since the summer of 2016, it should be recalled that the roots of the Turkish-Russian rapprochement actually date back to the early 2000s. The scholarly literature has explored the various dimensions of Turkish-Russian relations in the $21^{\text {st }}$ century. In particular, the growing asymmetric interdependence in economic relations and the intensification of institutional ties have attracted significant attention (Köstem, 2018; Öniş \& Y1lmaz, 2016). Some of these studies additionally highlight Russia's military involvement in Syria in September 2015 and the failed coup attempt that took place in Turkey in July 2016 as significant milestones in the shaping of the Turkish-Russian strategic relations (Erşen, 2017; Özdal 2020; Aktürk, 2019; Rüma \& Çelikpala, 2019). Yet, Turkey’s interest in developing closer ties with Russia cannot be fully understood in isolation from how the Turkish leaders have viewed the changing balances in the global, regional and domestic dynamics particularly since the second half of the 2000s.

The goal of this paper is to shed light on the main factors that have fostered the interest of the Turkish political elite in developing strategic relations with Russia. There is no doubt that Russia has been an important actor for Turkish foreign policymakers since the end of the Cold War. However, in the last few years, the significance attributed to Russia by the Turkish leaders visibly increased due to a number of reasons. We argue that a set of global, regional and domestic factors explain Turkey's strategic rapprochement towards Russia in the past few years. The paper, therefore, examines different levels of analyses with the purpose of uncovering Ankara's motivations for fostering closer ties with Russia.

First, especially after the global financial crisis in 2008, Russia managed to successfully realign itself with rising powers like China and India, while also strengthening its traditional position as a global player in world politics. Second, in addition to its strong influence in the Black Sea, the Caucasus and Central Asia, it has become a major actor in other regions in the immediate neighborhood of Turkey such as the Middle East and the East Mediterranean. And finally, the failed coup attempt of July 2016 in Turkey has 
added a strong psychological dimension to the Turkish-Russian rapprochement which had already been based on strong economic links in trade, energy and tourism. Close personal ties between President Erdoğan and President Putin in particular seem to have further consolidated Turkey's search for a stronger partnership with Russia. The following sections of the paper discuss the key dynamics of each level of analysis, namely global, regional and domestic, on the improvement of Turkish-Russian relations. The concluding section summarizes the argument and discusses its major implications.

\section{Global Dynamics}

Although it is no longer one of the two superpowers of the world as it had been during the Cold War, Russia is still regarded as one of the main global powers for a number of reasons. Geographically, it is the largest country in the world with its immense size and large territories in Europe and Asia. This truly Eurasian character enables Russia to play a global role and develop special relations with other global powers such as the US, China and the EU. It also provides Moscow with significant geopolitical leverage in the Eurasian space which has become increasingly significant for international relations since the end of the Cold War due to its vast potential of natural resources - particularly oil and natural gas. For Moscow, keeping a degree of control in Eurasia in this regard is crucial not only in terms of retaining its status as a global power, but also due to the fact that Russia itself is one of the leading producers of oil and natural gas (U.S. Energy Information Administration, 2019; International Energy Agency, 2019). Being such an "energy superpower" gives Moscow additional influence in international relations as it can effectively use this economic advantage to achieve its political objectives vis-à-vis other countries.

Russia also plays a very important role in international diplomacy, since it is one of the five permanent members of the United Nations Security Council (UNSC) and therefore possesses the right to veto any decision that runs against its own interests. This gives Moscow a remarkable leverage in global politics even in regions that are not of immediate interest for Russian foreign policy - such as Latin America or Sub-Saharan Africa. Perhaps more importantly, Russia is one of the leading powers of the so-called "nuclear club". In fact, more than 90 percent of all the nuclear warheads in the world belong to either Russia or the US, which provides an extraordinary influence to these two countries in the shaping of the agenda of international relations (Arms Control Association, 2019). In the past decade, Russia has also gained superiority in the global market of nuclear power plants as Russian official nuclear agency Rosatom has completed the construction of power plants in many countries including India, China and Iran (Aris, 2019).

There is a general consensus among the international relations scholars that Russia's role as a global power eroded significantly due to its serious political and economic problems in the 1990s. This trend was gradually reversed by President Vladimir Putin in the following decade as a result of a number of bold political and economic reforms he initiated at home and his determination to make greater use of Russia's hard power capabilities in foreign policy. Particularly with the help of high oil and natural gas prices throughout the 2000 s, Russia achieved impressive economic growth rates which also permitted it to finance an impressive military modernization program (Valdai Discussion Club, 2012). 
In foreign policy, on the other hand, Putin embraced the concept of "multipolarity" which was introduced to Russian foreign policy lexicon by former Russian Prime Minister Yevgeny Primakov in the mid-1990s to highlight the new role of Russia as one of the main power poles in the world. As a foreign policy doctrine, multipolarity envisions not only Russia's economic and military dominance in the post-Soviet space, but also an end to US unilateralism in world politics through close cooperation with the EU, China and India (Makarychev \& Morozov, 2011). In other words, multilateral cooperation with other global and regional powers has become extremely important for Putin's Russia in order to deter the US from taking unilateral actions in international relations.

One of Russia's key partners in the quest for a multipolar world order has been China. While the two countries have intensified their diplomatic cooperation in the UNSC as well as the Shanghai Cooperation Organization (SCO) and formed an informal diplomatic bloc against the US and NATO regarding a number of regional issues like Iraq, Iran, Syria and Kosovo, they have also quickly intensified their economic and military links through bilateral agreements. Following the 2008 financial crisis, which also quite negatively affected the Russian economy, it became even more important for Russia to remain close to the so-called rising powers that included not only China, but also India and Brazil (Johnson \& Köstem, 2016). It should be noted in this regard that the first ever summit of the newly created BRICS grouping was held in the Russian city of Ekaterinburg back to back with the SCO summit in June 2009. Dmitry Medvedev, who was the Russian president at the time, even labelled the joint SCO and BRICS summits as the "epicenter of world politics" (Kremlin.ru, 2009; Stuenkel, 2020). In short, at a time when the Western economies dealt with the aftershocks of the global financial crisis, Putin's Russia successfully realigned itself with the rising powers of the world despite its own economic limitations (Parlar Dal \& Erşen, 2020).

As Moscow's relations with the US and EU were further strained following the crisis in Ukraine - particularly after Russia's annexation of Crimea and military involvement in Syria in the 2014-2015 period - the rapprochement with China became even more significant. In addition to acting in consensus in regional issues like Libya, Syria, North Korea and Iran, Russia and China also decided to harmonize their grand economic projects in the Eurasian space - the Russia-led Eurasian Economic Union (EAEU) and China-led Belt and Road Initiative (BRI). In 2016, Moscow even announced a "Greater Eurasian Partnership" project, with the goal of enhancing economic connectivity between the EAEU and BRI and extend the EAEU's economic reach to the Asia-Pacific (Köstem, 2019a). Immediately after the US and the EU imposed sanctions on the Russian economy in 2014 due to Russia's annexation of Crimea, Moscow strengthened its so-called "pivot to Asia" and consolidated its strategic partnership with Beijing. For example, in May 2014, the two countries signed a natural gas deal worth 400 billion dollars, which had long been delayed due to various reasons (Johnson \& Köstem, 2016, p. 210). During the same period, Russia also signed lucrative arms deals with both China and India including the sale of the S-400 missile system to both countries.

For Turkey, which has traditionally treated Moscow as an important balance in its relations with the West since the late Ottoman era, the rising significance of the RussianChinese axis in world politics after 2008 not only signifies the emergence of a multipolar world order, but also provides a new and powerful element of balance in Turkish foreign 
policy. It should be noted that Turkey's economic relations with both Russia and China have steadily improved after the global financial crisis. In fact, these two countries are currently among the top three trade partners of Turkey together with Germany. More importantly, due to its impressive economic growth in the 2000s, Turkey itself has often been described as a rising power or an emerging middle power by many scholars, which has rendered international organizations like the SCO, BRICS and G-20 even more attractive for the Turkish leaders (Öniş \& Kutlay, 2013; Oğuzlu \& Parlar Dal, 2013).

In 2012, Turkey became the only NATO member to have formed close institutional links with the SCO by becoming a "dialogue partner" of this organization (Contessi, 2019, p. 93). In July 2018, President Erdoğan attended the BRICS Summit in Johannesburg and expressed his desire to enhance Turkey's cooperation with BRICS in trade, investment and development (Presidency of the Republic of Turkey, 2018). Most recently, the Turkish Ministry of Foreign Affairs declared the "Asia Anew" initiative which similarly aims to develop Turkey's economic links with the Asian countries (Daily Sabah, 2019). In all these newly launched foreign policy initiatives, Russia plays a very important role due to its extended global reach as well as its evolving strategic partnership with China in global issues like nuclear disarmament and energy networks. This makes the Turkish leaders more interested in becoming actively engaged with Eurasian-based regional cooperation projects like the Greater Eurasian Partnership. Although it is not yet quite clear what kind of a role Turkey could play in such projects due to its traditionally strong economic and strategic links with the West, the development of Eurasia as a geopolitical concept has been on the agenda of Turkish political and intellectual circles since the early 2000s mainly due to the strengthened influence of Russia in world politics during the Putin era (Erşen, 2013).

At the same time however, it should be noted that Turkish-Russian relations do not entail a global character as they have rather developed around regional rather than global issues. Nevertheless, Russia's growing activism in world politics in the 2000s and the decline of the US hegemony after the global financial crisis have inevitably shaped and factored into the foreign policy decision-making in Turkey. Thus, Turkey's desire for closer political, economic and military relations with Russia should be understood first of all in light of the Turkish leaders' perceptions about the tectonic shifts taking place in the global balance of power. Since 2008, the influence of the US and EU in world politics has been increasingly challenged by non-Western powers like China and India, while Russia - mainly as a result of the strong links it has formed with these countries - seems to have become an important link that connects Turkey to organizations like the BRICS and SCO. Putin's discourse of multipolarity in world politics is also in conformity with President Erdoğan's famous slogan "the world is bigger than five", which similarly emphasizes the need to create a more inclusive international decision-making system. On the other hand, Turkey's increasingly complicated relations with both the US and EU in the last few years increase the appeal of Russia for the Turkish policymakers as they continue to view Moscow as an important balance against the West in global politics.

\section{Regional Dynamics}

Although the two countries do not share a land border, Russia is often regarded as one of the most important neighbors of Turkey. This is mainly due to the traditionally strong 
Russian influence in Turkey's three neighboring regions: the Caucasus, the Black Sea and the Balkans. In addition, Russia has very close links with the Turkic republics of Central Asia which have become quite significant for Turkish foreign policy in the post-Cold War period. Particularly in the last few years, Ankara has been striving to strengthen its relations with the Central Asian countries through new multilateral platforms like the Turkic Council (Köstem, 2019b, pp. 115-116). Developing positive relations with Russia in this sense is of critical importance for the success of political, economic and cultural cooperation initiatives launched by Turkey in Central Asia.

Regarding the Caucasus and Black Sea, on the other hand, the geopolitical interests of Turkey and Russia have not been very compatible. Turkey developed significant strategic links with Azerbaijan, Georgia and Ukraine throughout the 2000s, while Russia's relations with the latter two remain quite troubled due to its war with Georgia in 2008 and the ongoing conflicts in Crimea and Donbas that emerged as a result of the Euromaidan protests in Ukraine in 2014. On the other hand, Moscow established very close political, economic and military ties with Armenia which currently does not have any diplomatic relations with Turkey. Armenia also hosts a Russian military base in Gyumri, which is very close to the Turkish border and became a full member of the Russian-led EAEU in 2015. Conversely, Turkey regards Azerbaijan as a strategic partner, and views it as a pivotal state for its broader outlook towards the Caucasus and Central Asia (Köstem, 2019b).

Russia also enjoys significant geopolitical influence over the so-called "frozen conflicts" in South Ossetia, Abkhazia, Nagorno-Karabakh and Transnistria. The escalation of such conflicts may undermine not only the emerging trilateral strategic cooperation between Turkey, Azerbaijan and Georgia in the region, but also negatively affect the ongoing energy projects such as the TANAP natural gas pipeline which forms the backbone of the "Southern Gas Corridor" initiative supported by the EU. Turkey, on the other hand, is concerned about a possible military escalation between Russia and NATO in the Black Sea which could upset the delicate geopolitical balance established in this region as a result of the 1936 Montreux Straits Convention (Çelikpala \& Erşen, 2018). A potential Russia-NATO conflict could also threaten the successful operation of the TurkStream natural gas pipeline which was inaugurated by Turkey and Russia in January 2020. It should also be mentioned that in addition to contributing to Turkey's energy supply security, TANAP and TurkStream projects together serve the Turkish government's long-standing goal of making Turkey an energy hub between Europe and Asia (Erşen \& Çelikpala, 2019).

For all the reasons stated above, Turkey's policy with regard to the Caucasus and Black Sea has been based on the maintenance of a close regional dialogue with Moscow. For instance, unlike many NATO countries, Turkey did not join the sanctions against Russia following the crisis in Ukraine in 2014. At the same time, however, it continued to support the territorial integrity of Ukraine and rejected the Russian annexation of Crimea. For instance, Ankara has consistently referred to Russia's annexation of Crimea as a clear violation of international law and aimed to protect the rights of Crimean Tatars, a Turkic minority with strong political and societal links to Turkey. In a press release of August 2020, the Turkish Ministry of Foreign Affairs even criticized the "systemic oppression and intimidation campaign against Crimean Tatars" and announced that Turkey would "continue to stand by its kinsmen" (Republic of Turkey Ministry of Foreign Affairs, 2020). 
Turkey has also supported regional peace initiatives in the Caucasus including the efforts of the OSCE's Minsk Group for the resolution of the Nagorno-Karabakh conflict. After the Russian-Georgian war in 2008, it proposed the creation of a "Caucasus Stability and Cooperation Platform" to resolve the regional conflicts together with Russia and the countries of the Caucasus (Gültekin Punsmann, 2009). Although this platform could not be activated in the later years, it can be viewed as a sign that Turkey has been willing to treat Russia as an important partner in the solution of the regional conflicts in the Caucasus.

With its active involvement in the Syrian civil war, Russia has also become a prominent actor in the Middle East and the East Mediterranean. Since the outbreak of the Syrian conflict in 2011, it has resorted to its veto power in the UNSC sixteen times, effectively blocking greater international pressure over the Assad regime. It has also actively collaborated with Iran to help the Assad regime in defeating the rebel groups supported mainly by Turkey and the West. The Russian military campaign launched in Syria in September 2015, on the other hand, radically changed the geopolitical balance in the region. Russia's military intervention in Syria also coincided with the emergence of a tactical partnership between the US and the PYD/YPG which is recognized by Turkey as a terrorist organization due to its strong links with the PKK. This new US policy in Syria has not only alienated Ankara, but also prepared the grounds for the development of a gradual strategic rapprochement between Turkey, Russia and Iran. Although the downing of a Russian fighter jet by the Turkish forces over the Turkish-Syrian border in November 2015 caused a serious crisis between Ankara and Moscow which could only be resolved in the summer of 2016 with Erdoğan's letter of regret to Putin, the strengthened military ties between the US and PYD/YPG urged the Turkish leaders to move closer to the Russia-Iran axis in Syria (Đidić \& Kösebalaban, 2019; Erşen, 2017; Köstem, 2020; Özdal, 2020). Eventually, Turkey, Russia and Iran launched the "Astana talks" in December 2016 as a major diplomatic platform bringing the representatives of the Assad regime and the Syrian opposition around the negotiation table. Leaders of these three countries have also met several times through the Sochi format, and negotiated the terms of a ceasefire as well as a political settlement in Syria (Köstem, 2020, pp. 9-10).

The enhanced military-political dialogue with Russia and Iran has enabled the Turkish Armed Forces to conduct three large cross-border military operations in Syria. As a result of the "Operation Euphrates Shield" launched in August 2016, the "Operation Olive Branch" launched in January 2018, and finally the "Operation Peace Spring" launched in October 2019, Turkish forces achieved to clear a large area in northern Syria along the Turkish border from both the DAESH and YPG militants. In addition, Ankara established twelve military observation posts in the Idlib province of northwestern Syria and brokered a ceasefire agreement with Moscow in September 2018 to resolve the crisis in Idlib with the purpose of setting up a weapons-free zone (Anadolu Agency, 2018), even though this ceasefire collapsed in early 2020 due to the intensified offensive of the Assad regime. Yet, following the killing of dozens of Turkish soldiers in Idlib by airstrikes in February 2020, Ankara and Moscow once again facilitated a new deal for the cessation of hostilities in this strategically located province. While the agreement has been in force since March 2020, the Turkish military has also consolidated its presence in Idlib. At the same time, however, it would not be surprising to see a new round of Russian-backed 
regime offensives in Idlib. In short, it has become clear once again for the Turkish leaders after all these developments that maintaining a close military dialogue with Moscow in Syria is crucial in light of the central role Russia has continued to play in the Syrian conflict (Suchkov, 2020).

It is worth mentioning that its active involvement in Syria has also enabled Russia to largely increase its influence in the affairs of the Middle East. Apart from strengthening its bilateral ties with almost all of the countries in the region, Moscow has achieved to advance its economic interests through lucrative agreements signed in the field of arms sales, construction of nuclear power plants and development of oil and natural gas fields. It should be noted in this regard that even the closest US strategic partners in the region such as Israel and Saudi Arabia have developed strong political, economic and military links with Russia in the last few years.

This renewed influence in the Middle East has also permitted Moscow to play a greater geopolitical role in the East Mediterranean region which has become much more significant in world politics after the discovery of large offshore natural gas reserves. Considering that both the US and EU are currently supporting a position that is contrary to Turkey's interests in the East Mediterranean natural gas issue, it is quite important for Ankara to maintain its strong regional dialogue with Moscow in order not to be sidelined in the region - particularly when one considers that Russia enjoys close relations with Israel, Egypt, Greece and Greek Cypriots and the Russian energy companies are quite active in the East Mediterranean. It is interesting to note for instance that in an interview with Anadolu Agency, Russian Energy Minister Alexander Novak said it could be possible for Russia to cooperate with Turkey in the region (Anadolu Agency, 2019; Starodubtsev, 2019). In September 2020, on the other hand, amidst growing tensions between Turkey and Greece around Turkey's oil and gas exploration missions in the East Mediterranean, Russian Minister of Foreign Affairs Sergei Lavrov suggested Russia's mediation to ease the tensions (Aljazeera, 2020).

Since 2019, the Libyan issue has also indicated the importance of Russia in Turkey's regional strategy. As with many other regional conflicts in the Middle East and North Africa, Turkey and Russia support opposite factions and desire divergent outcomes in the ongoing Libyan conflict. The Western-led military intervention in Libya and the toppling of Qaddafi in 2011 was a turning point for Russia's position vis-à-vis humanitarian intervention in world politics. In fact, it is argued that Russia's decisive position in Syria owes much to its relative inaction in the NATO-led regime change in Libya (Averre \& Davies, 2015). As the conflict in Libya evolved, Turkey has offered diplomatic and military support to the Government of National Accord (GNA) in Tripoli, which is the legitimate authority representing the country in the eyes of the UN, while Russia has decided to back the Libyan warlord Haftar, who is currently controlling a considerable part of Libyan territory. Many analysts indicated that in addition to maintaining its economic interests in Libya, Russia could emerge as a powerbroker in the war-torn country just like it has done so in Syria (Souleimanov, 2019). However, in June 2020, Turkish-backed GNA forces stopped a fourteen-month siege of Haftar forces in Tripoli. Given Haftar's deteriorating military power, Moscow has increasingly backed Aguila Saleh Issa, the speaker of the Tobruk-based House of Representatives (Belenkaya, 2020). Since late 2019, diplomats from both sides 
have held several rounds of consultations for a political solution to the conflict in Libya (UN News, 2020). Regardless of how the conflict evolves in the near future, Russia's position in Libya and particularly its support for Haftar and Saleh in this regard will be a crucial dimension factoring into Turkey's plans in Libya and the East Mediterranean.

\section{Domestic Dynamics}

Ankara's interest in building closer relations with Moscow is also related with a number of important domestic concerns. Above all, Russia has become one of the top economic partners of Turkey in the 2000s as a result of the thriving relations between the two countries in key sectors like trade, energy, tourism and construction. While the bilateral trade volume was only around 4 billion dollars at the beginning of the $2000 \mathrm{~s}$, it reached an all-time high with 38 billion dollars in 2008 which made Russia the top trading partner of Turkey for that year. Although this figure has significantly dropped in the following years due to the impacts of the global financial crisis, Russia nevertheless maintained its position as one of the most important trade partners of Turkey. In 2019, for instance, it came second only after Germany in the list of Turkey's top trading partners with a trade volume of around 27 billion dollars (T.C. Ticaret Bakanlığı, 2019). Although the Turkish government has repeatedly declared its objective to increase this figure to 100 billion dollars in the longer term, it looks like an unrealistic goal given the persistent problems as well as the absence of economic integration between the two countries.

Energy is undoubtedly one of the main driving engines of the Turkish-Russian economic relations. In 2018, around 47 percent of Turkish natural gas imports and 25 percent of oil and other petroleum product imports came from Russia (EPDK, 2019a; EPDK, 2019b). Yet, it should also be noted that Turkey's heavy dependency on the Russian oil and natural gas products has been gradually decreasing over the last few years. For example, in 2019, with 15,2 bcm Russia accounted for 33,6 percent of the Turkish total natural gas imports, which. corresponds to a 36 percent decrease in Turkey's natural gas imports from Russia compared to the previous year. Still, these figures indicate that Russia continues to be an indispensable country for Turkey's energy strategy. The energy relationship between the two countries has been further strengthened with the initiation of two mega energy projects in the last decade. Ankara and Moscow signed an agreement in 2010 for the construction of Turkey's first nuclear power plant in the Mediterranean town of Akkuyu by Rosatom. Estimated to cost more than 20 billion dollars, the Akkuyu NPP is composed of four 1,200-megawatt reactors that are expected to meet around 10 percent of Turkey's electricity demand when the plant becomes operational in 2023.

The second mega energy project is the TurkStream natural gas pipeline which was first announced by President Putin during his visit to Ankara in 2014. The first string of the pipeline has been designed to transport around 16 billion cubic meters of gas annually for Turkish domestic consumption, while the second string is planned to deliver Russian gas directly to the European market and therefore strengthen Turkey's role as an energy corridor in Eurasia. The project also supports Russia's goal of bypassing Ukraine in delivering its natural gas to Europe. Following the Turkish-Russian intergovernmental agreement of October 2016, the construction of the TurkStream pipeline started in May 2017 and the pipeline was finally inaugurated and started shipping gas in January 2020. 
Tourism and construction are the two other important sectors that promote the deepening of Turkish-Russian relations in the economic sphere. Only in 2018, around 6 million Russian nationals visited Turkey - marking a 25 percent increase compared with the previous year (Hürriyet Daily News, 2018). Although this number significantly decreased in 2020 due to the Covid-19 outbreak, Turkey still remains the most popular destination for Russian tourists as also evidenced by thousands of Russian people who rushed to Antalya and other Turkish cities once the travel restrictions were eased in the summer. In the construction sector, on the other hand, the total investment of the Turkish construction companies in Russia reached almost 70 billion dollars as of February 2019 (Rus Türk İşadamları Birliği, 2019).

Despite such strong economic links, until the attempted coup of July 2016, it was quite difficult to create an atmosphere of trust between Turkey and Russia at the governmental and public level. This is mainly due to the fact that the history of Turkish-Russian relations is dominated by fierce geopolitical rivalry and wars rather than friendly ties and cooperation. Even during the post-Cold War era, which witnessed a remarkable development of political and economic relations between the two countries, the regional disagreements have prevented the emergence of a genuine Turkish-Russian strategic rapprochement (Erşen, 2011). It is clear in this regard that the failed coup attempt in Turkey on July 15, 2016 has significantly changed this picture. Although the attempt was quickly repelled by the Turkish security forces, Ankara was quite disappointed in the muted and hesitant reaction of its NATO allies about this incident, while Moscow gave outright support to the Turkish government against the coup plotters. The reluctance of the US authorities to extradite the Pennsylvania-based cleric Fetullah Gülen, who Turkey accuses of orchestrating the coup attempt as well as leading the Gülenist Terror Organization (FETÖ), has further alienated Ankara from Washington in the following period.

Moscow, on the other hand, had already banned the activities of FETÖ as early as 2008. Russia's consistent attitude toward the Gülenists created a strong common ground between President Erdoğan and President Putin (Immigration and Refugee Board of Canada, 2015). In the post-July 15 period, the friendly dialogue between the two leaders became even more remarkable. Only in 2018, for instance, they personally met seven times on different occasions and spoke eighteen times with each other on the phone (TRT Haber, 2019). They have also publicly announced their affinity towards each other in various platforms. It is clear in this regard that the warm relations between the two presidents have greatly contributed to the improvement of Turkish-Russian relations after 2016. In fact, even the rapid mending of the Turkish-Russian political and economic ties in the aftermath of the fighter jet crisis of November 2015 could be possible due to the working relationship between Putin and Erdoğan. In addition, the above-mentioned ceasefires over Idlib typically came through as a result of the long discussions between the two leaders. Therefore, one could argue that the individual consultations between Putin and Erdoğan have been more influential than institutional channels such as the High Level Cooperation Council meetings that have taken place since 2010. Although it would be too bold to claim that the two leaders have achieved to build a relationship that is based on mutual trust in the post-2016 period, it could be argued that their personal dialogue which also provides the basis for the "marriage of convenience" between Ankara and Moscow has proven resilient despite all obstacles (Öğütçü \& Bechev, 2018). 
The past few years have also been marked by intensified debates about growing authoritarianism in Turkish politics and the eradication of democratic rights and freedoms. While the US and the EU have harshly criticized this trend, Russia has not interfered with Turkish politics, which also significantly contributed to Russia's appeal to Turkish decision makers as a reliable partner. Moreover, the Russian style of top-down executive control, in which the role of the parliament is diminished under a highly centralized presidential system, seems to have been quite attractive for Turkish leaders. The recent literature has already started discussing the similarities and differences between the Turkish and Russian political systems in this regard (White \& Herzog, 2016).

What is more interesting about this new phase of Turkish-Russian rapprochement is that it is also being reflected in the public reactions in Turkey. A recently conducted opinion poll, for example, revealed that more than 60 percent of the Turkish people view the US as the most important threat against Turkey's national interests, while 14 percent believes strategic cooperation with Russia can become an alternative to Turkey's stalled EU membership process (Kadir Has University, 2018). President Erdoğan already expressed his interest in different occasions to strengthen Turkey's relations with the SCO which is led by Russia and China (Sputnik Türkiye, 2016). While it is not realistic to expect Turkey's full membership in the SCO in the near future, it is still important to note that the perceptions of both the Turkish government and public about Russia have been changing in a remarkable way in the post-July 15 period.

\section{Conclusion: Turkey between Russia and the Transatlantic Alliance}

As Balta (2019) recently demonstrated, power asymmetry in security and economic relations, varying national interests, both states' relations with the West, as well as domestic regime types are at play in shaping the various dimensions of Turkish-Russian relations. At the same time, the bilateral relationship between the two countries has survived various moments of crises in the past century (Hirst \& Isci, 2020). This article has argued that a monocausal approach to Turkish-Russian relations is insufficient and various factors at the global, regional and domestic levels help explain Turkey's intensifying and complex ties with Russia in the past decade. That being said, these multiple factors are insufficient for the transformation of Turkish-Russian alignment into a strategic partnership as the two countries continue to prefer divergent outcomes in various regional issues.

On the other hand, it is worth mentioning that Turkish-Russian relations have come a long way since the 1990s when the political and economic links between the two countries were largely overshadowed by their disagreements with regard to a number of regional issues in the Caucasus, Central Asia and the Black Sea region. It seems that the thriving economic ties especially in the field of energy provided a significant momentum to the development of a regional dialogue between the two countries in the 2000s. Although it may still be too early to define the Turkish-Russian alignment as a genuine strategic partnership, the rapidly developing relations between Ankara and Moscow in the post2016 period are quite remarkable especially at a time when both countries have important issues to resolve with the US and EU. For instance, Russia is still subject to the Western economic sanctions and Turkey's relations with its NATO allies have become frostier in the last few years due to a variety of problems. Against this background, it seems quite 
natural for the two neighbors to approach each other considering that they have already established solid bilateral links in various political and economic spheres.

In the past decade, Turkey's ties with its traditional transatlantic allies have been strained due to mutual frustration in regional crises and the growing democracy deficit in Turkey. Turkey's alignment with Russia over the Syrian conflict has exacerbated the problems in Turkish-US relations (Balc1 2019; Buhari-Gülmez 2020, pp. 475-476). Yet, it should be emphasized that Turkey is still one of the key members of the NATO alliance which is regarded by Russia as a major geopolitical rival in world politics. Turkey's strong commitment to the alliance during the NATO summit of December 2019, which took place in London, for instance, has demonstrated once again that it would be quite difficult to view Russia as a potential new ally for Turkey. On the other hand, although Ankara's EU accession process currently seems stalled, it is nevertheless an official candidate country and enjoys significant political and economic links with the EU countries. Considering the remarkable trade deficit which works against Turkey's economic interests in its relations with Russia and China, it is not very plausible to assume that Ankara has been trying to replace its long-standing strategic relations with the West with a new strategic axis. Even with the US, despite all the problems in the bilateral relations, Turkish officials seem to have maintained a significant degree of dialogue - the best example of which can be witnessed in the October 2019 deal between Turkey and the US over northern Syria. Despite persistent disagreements over the PYD/YPG, Washington continues to engage in active diplomacy to find a common ground with Ankara as demonstrated by the most recent developments in Idlib.

More importantly, Turkey's position regarding a number of significant regional issues in the Black Sea, the Caucasus and the Balkans is closer to the position of its NATO allies, rather than Russia. The armed clashes that have resumed between Armenia and Azerbaijan over Nagorno-Karabakh in 2020 for instance could potentially drag Turkey and Russia into a new geopolitical confrontation in the Caucasus. Even in Syria, where Turkish-Russian rapprochement is most obvious, there are many issues that need to be resolved between Ankara and Moscow including the political future of Assad, the deteriorating situation in Idlib, the future of Turkish armed forces in Syria and Russia's special links with the PYD/ YPG (Köstem, 2020, pp. 12-17). Ankara seems to have taken into account the backlash from its NATO allies and especially potential sanctions from the US over its acquisition and deployment of Russian S-400 missile defense systems. Yet, the fact that the Turkish leaders have so far carefully refrained from officially announcing the activation of the S-400s, although they were tested in Sinop in October 2020 over strenuous US objections, demonstrates that Ankara might be working on a middle ground to avoid US sanctions and ease tensions with NATO. Disagreements over the natural gas resources of the East Mediterranean, Russia's position in Turkey's current disagreements with Greece, Egypt, Israel and France as well as the conflict in Libya will also continue to be crucial stress tests for Turkey's geopolitical alignment with Russia in the foreseeable future.

In short, despite all the recent remarks about the emergence of a Turkish-Russian strategic axis in Eurasia, it is important to view Ankara's interest in developing closer relations with Moscow more in the light of its global, regional and domestic policy considerations, rather than a deliberate attempt to strategically shift the axis of Turkish 
foreign policy towards Russia. Due to their geographical proximity and extensive economic links, Turkey and Russia will always need to maintain their strategic dialogue. However, relations with Russia should be viewed within the framework of Turkey's multidimensional foreign policy which also includes the maintenance of close political, economic and military ties with the West as part of the transatlantic alliance.

Peer-review: Externally peer-reviewed.

Conflict of Interest: The authors have no conflict of interest to declare.

Grant Support: The authors declared that this study has received no financial support.

\section{References}

Aktürk, Ș. (2019). Relations between Russia and Turkey Before, During, and After the Failed Coup of 2016. Insight Turkey, 21(4), 97-114.

Aljazeera. (2020, September 8). Russia to Mediate in Eastern Mediterranean Crisis: Lavrov. Retrieved from https://www.aljazeera.com/news/2020/09/08/russia-ready-to-mediate-in-eastern-mediterranean-crisis-lavrov/.

Anadolu Agency. (2018, September 9). Turkey, Russia Agree on 'Weapons-Free Zone' in Idlib. Retrieved from https://www.aa.com.tr/en/energy/energy-security/turkey-russia-agree-on-weapons-free-zone-in$\mathrm{idlib} / 21653$.

Anadolu Agency. (2019, July 26). Russia, Turkey Cooperation Possible in East Med.: Novak. Retrieved from https://www.aa.com.tr/en/energy/energy-diplomacy/russia-turkey-cooperation-possible-in-east-mednovak/26176.

Aris, B. (2019, May 9). Russia's Nuclear Power Exports Are Booming. The Moscow Times. Retrieved from https://www.themoscowtimes.com/2019/05/09/russias-nuclear-power-exports-are-booming-a65533

Arms Control Association. (2019). Nuclear Weapons: Who Has What at a Glance. Retrieved from https://www. armscontrol.org/factsheets/Nuclearweaponswhohaswhat

Averre, D. \& Davies L. (2015). Russia, Humanitarian Intervention and the Responsibility to Protect: The Case of Syria. International Affairs, 91(4), 813-834.

Balc1, A. (2019). A Three-level Analysis of Turkey's Crisis with the U.S.-led Order. Insight Turkey, 21(4), 13-24.

Balta, E. (2019). From Geopolitical Competition to Strategic Partnership: Turkey and Russia after the Cold War. Uluslararası İlişkiler, 16(63), 69-86.

Belenkaya, M. (2020, August 31). In Libya's War, Russia is Directionless - and Falling Behind. The Moscow Times. Retrieved from https://www.themoscowtimes.com/2020/08/31/in-libyas-war-russia-is-directionlessand-falling-behind-a71286.

Buhari Gülmez, Didem (2020). The Resilience of the US-Turkey Alliance: Divergent Threat Perceptions and Worldviews. Contemporary Politics, 26(4), 475-492.

Contessi, N. P. (2019). Turkey and the Shanghai Cooperation Organization: Common Values, Economics or Pure Geopolitics?. In Turkey's Pivot to Eurasia: Geopolitics and Foreign Policy in a Changing World Order (pp. 93-110). Routledge.

Çelikpala, M., \& Erşen, E. (2018). Turkey’s Black Sea Predicament: Challenging or Accommodating Russia? Perceptions: Journal of International Affairs, 23(2), 72-92.

Daily Sabah. (2019, August 6). Turkey Launches 'Asia Anew'Initiative in Diplomacy. Retrieved from https:// www.dailysabah.com/diplomacy/2019/08/06/turkey-launches-asia-anew-initiative-in-diplomacy.

Đidić, A., \& Kösebalaban, H. (2019). Turkey’s Rapprochement with Russia: Assertive Bandwagoning. The International Spectator, 54(3), 123-138.

EPDK. (2019a). Petrol Piyasası 2018 Sektör Raporu. Retrieved from https://www.epdk.org.tr/Detay/ Icerik/3-0-107/yillik-sektor-raporu

EPDK. (2019b). Doğalgaz Piyasası 2018 Sektör Raporu. Retrieved from https://www.epdk.org.tr/Detay/ Icerik/5-5847/2018-yillik-sektor-raporlari-yayinlanmistir

Erşen, E. (2011). Turkey and Russia: An Emerging 'Strategic Axis' in Eurasia? EurOrient, 35-36, $263-285$.

Erşen, E. (2013). The Evolution of 'Eurasia' as a Geopolitical Concept in Post-Cold War Turkey. Geopolitics 18 (1), 24-44.

Erşen, E. (2017). Evaluating the Fighter Jet Crisis in Turkish-Russian Relations. Insight Turkey, 19(4), 85-104.

Erşen, E., \& Çelikpala, M. (2019). Turkey and the Changing Energy Geopolitics of Eurasia. Energy Policy, 128, 584-592.

Gultekin-Punsmann, B. (2009). The Caucasus Stability and Cooperation Platform: An Attempt to Foster Regional Accountability. Athens: International Centre for Black Sea Studies.

Hirst, S., \& Isci, O. (2020). Smokestacks and Pipelines: Russian-Turkish Relations and the Persistence of Economic Development. Diplomatic History, https:/doi.org/10.1093/dh/dhaa046. 
Hürriyet Daily News. (2018, December 27). Turkey was Russian Tourists' Top Destination in 2018. Retrieved from http:/www.hurriyetdailynews.com/turkey-was-russian-tourists-top-destination-in-2018-140044.

Immigration and Refugee Board of Canada. (2015, February 19). Russia: The Fethullah Gülen Movement (Hizmet Movement), Including Activities and Regions of Operation; Treatment of Members by Society and Authorities; Recourse Available to Members, Including State Protection (2002-January 2015). Retrieved from https://www.refworld.org/docid/56b06aa24.html

International Energy Agency. (2019). Gas 2019. Retrieved from https://www.iea.org/gas2019/.

Johnson, J., \& Köstem, S. (2016). Frustrated Leadership: Russia's Economic Alternative to the West. Global Policy, 7(2), 207-216.

Johnson, K., \& Gramer, R. (2019, July 19). Who Lost Turkey? Foreign Policy. Retrieved from https:// foreignpolicy.com/2019/07/19/who-lost-turkey-middle-east-s-400-missile-deal-russia-syria-iraq-kurdishunited-states-nato-alliance-partners-allies-adversaries/

Kadir Has Üniversitesi. (2018, June 6). Kadir Has Üniversitesi Dış Politika Kamuoyu Algıları Araştırması 2018 Sonuçları Açıklandı.

Retrieved from http://www.khas.edu.tr/news/1885.

Karlıdağ, I., \& Borshchevskii, G. (2019, August 27). Analysis: Does S-400 Deal with Russia Signal a Shift in Turkey's Alignment? BBC Monitoring. Retrieved from https://monitoring.bbc.co.uk/product/c2011oyk

Köstem, S. (2018). The Political Economy of Turkish-Russian Relations: Dynamics of Asymmetric Interdependence. Perceptions: Journal of International Affairs, 23(2), 10-32.

Köstem, S. (2019a). Russia's Search for a Greater Eurasia: Origins, Promises, and Prospects. Kennan Cable, (40).

Köstem, S. (2019b). Geopolitics, Identity and Beyond: Turkey's Renewed Interest in the Caucasus and Central Asia. In Turkey's Pivot to Eurasia: Geopolitics and Foreign Policy in a Changing World Order (pp. 111128). Routledge

Köstem, S. (2020). Russian-Turkish Cooperation in Syria: Geopolitical Alignment with Limits. Cambridge Review of International Affairs, 1-23.

Kremlin.ru. (2019, June 16). Vstupitel'noe slovo na zasedanii glav gosudarstv gruppy BRIK v uzkom sostave. Retrieved from http://news.kremlin.ru/transcripts/4474

Makarychev, A. \& Morozov, V. (2011). Multilateralism, Multipolarity, and Beyond: Menu of Russia's Policy Strategies. Global Governance, 17(3), 353-374.

Oğuzlu, T., \& Parlar Dal, E. (2013). Decoding Turkey’s Rise: An Introduction. Turkish Studies, 14(4), 617-636.

Öğütçü, M., \& Bechev, D. (2018). Will Turkey and Russia Become 'Strategic Allies' or Sustain a 'Marriage of Convenience'? Hürriyet Daily News. Retrieved from https://www.hurriyetdailynews.com/opinion/mehmetogutcu/will-turkey-and-russia-become-strategic-allies-or-sustain-a-marriage-of-convenience-127392.

Öniş, Z., \& Kutlay, M. (2013). Rising Powers in a Changing Global Order: The Political Economy of Turkey in the Age of BRICS. Third World Quarterly, 34(8), 1409-1426.

Öniş, Z., \& Yılmaz, Ş. (2016). Turkey and Russia in a Shifting Global Order: Cooperation, Conflict and Asymmetric Interdependence in a Turbulent Region. Third World Quarterly, 37(1), 71-95.

Özdal, H. (2020). Turkey-Russia Relations: Complex Cooperation. In Threats to Euro-Atlantic Security: Views from the Younger Generation Network (pp. 99-114). Palgrave Macmillan.

Parlar Dal, E., \& Erşen, E. (2020). Russia and the Changing International System: An Introduction. In Russia in the Changing International System (pp. 1-16). Palgrave Macmillan.

Presidency of the Republic of Turkey. (2018, July 25). President Erdoğan Goes to South Africa to Attend BRICS Summit. Retrieved from https:/www.tccb.gov.tr/en/news/542/95940/president-erdogan-goes-tosouth-africa-to-attend-brics-summit-.

Republic of Turkey Ministry of Foreign Affairs (2020, August 31). Press Release Regarding the Treatment of Crimean Tatars. Retrieved from http://www.mfa.gov.tr/no_-191_-kirim-tatarlarina-yonelik-muamele-hk. en.mfa.

Rus Türk İş Adamları Birliği. (2019 February). Rusya İnşaat Sektöründeki Gelişmeler ve Türk Firmalart. Retrieved from https://www.rtib.org/cms-uploads/inşaat-rusya-1.pdf.

Rüma, İ. \& Celikpala, M. (2019). Russian and Turkish Foreign Policy Activism in the Syrian Theater. Uluslararast Illişkiler Dergisi, 16(62), 65-84.

Souleimanov, E.A. (2019). Russia's Policy in the Libyan Civil War: A Cautious Engagement. Middle East Policy, 26(2), 95-103.

Sputnik Türkiye. (2016, November 20). Erdoğan: 'Şanghay Beşlisi İçerisinde Türkiye Niye Olmasın? 'Diyorum.

Retrieved from https://tr.sputniknews.com/turkiye/201611201025892702-erdogan-ab-sanghay-beslisi/.

Starodubtsev, I. (2019, May 27). Will Russia Back Turkey in the Eastern Mediterranean? The New Turkey. Retrieved from https://thenewturkey.org/will-russia-back-turkey-in-the-eastern-mediterranean.

Stuenkel, O. (2020). The BRICS and the Future of Global Order. Lexington Books.

Suchkov, M.A. (2020, March 6). Why New Russia-Turkey Deal on Idlib Matters. Al-Monitor. Retrieved from https:/www.al-monitor.com/pulse/originals/2020/03/russia-turkey-deal-idlib-important-putin-erdogan.html.

T.C. Ticaret Bakanlığı (2019). Dış Ticaret ve Başlıca Ekonomik Göstergeler Bülteni - 2019 Yıllık. Retrieved from https://ticaret.gov.tr/istatistikler/dis-ticaret-istatistikleri. 
TRT Haber. (2019, April 3). Cumhurbaşkanı Erdoğan Ille Putin 3’üncü Kez Bir Araya Gelecek. Retrieved from https://www.trthaber.com/haber/gundem/cumhurbaskani-erdogan-ile-putin-3uncu-kez-bir-arayagelecek-410698.html.

UN News. (2020, February 12). Libya: Security Council Demands Commitment to a 'Lasting Ceasefire'. Retrieved from https://news.un.org/en/story/2020/02/1057311.

U.S. Energy Information Administration. (2019). Frequently Asked Questions. Retrieved from https://www.eia. gov/tools/faqs/faq.php?id=709\&t=6

Valdai Discussion Club. (2012, July). Military Reform: Toward the New Look of the Russian Army. Retrieved from http://vid-1.rian.ru/ig/valdai/Military_reform_eng.pdf.

White, D. \& Herzog, M. (2016). Examining State $\bar{C}$ apacity in the Context of Electoral Authoritarianism, Regime Formation and Consolidation in Russia and Turkey. Southeast European and Black Sea Studies, 16(4), 551-569. 
